FILOZOFIA

Roč. 75,2020 , с̌. 7

DOI: https://doi.org/10.31577/filozofia.2020.75.7.1

\title{
PROBLÉM ZALOŽENÍ A LEGITIMIZACE LIDSKÝCH PRÁV
}

MIROSLAV VACURA, Vysoká škola ekonomická v Praze, Katedra filosofie, Praha, ČR

VACURA, M.: The Problem of Foundation and Legitimization of Human Rights

FILOZOFIA, 75, 2020, No 7, pp. $513-526$

Human rights are currently the subject of several complex questions that are political, social, or legal in its nature. In order to address these problems meaningfully, we must also take into account a more general philosophical context and we should have a clearer idea of what human rights are and on what foundations they are based. In the study, we discuss whether we currently have a fully philosophically based conception of the foundation and legitimization of human rights. We present various current approaches that are candidates for solving this problem and we offer their critical evaluation. The starting point for us is the idea of human rights as obvious truths and approaches derived from it based on rational or emotional evidence. We also deal with the possibility of establishment of human rights utilizing concept of natural law, utilitarian approaches, and conceptions based on the idea of dignity. Some other related theories and historical contexts of the analysed conceptions are also briefly mentioned. We wrap up the text with conclusion that a completely satisfactory philosophical theory of human rights is still not available, and we also put forward our recommendations for solving the presented problems of the investigated theories.

Keywords: Human rights - Evidence - Utilitarianism - Dignity

\section{Úvod}

Lidská práva jsou v současné době předmětem řady otázek: jsou veganská strava ve vězení, ${ }^{1}$ placená dovolená, ${ }^{2}$ umělá inteligence ${ }^{3}$ či neomezený počet potomkư ${ }^{4}$ základními lidskými právy? Tyto otázky mají rozměr politický, právní, ale také obecněji

\footnotetext{
${ }^{1}$ Obvodní soud pro Prahu 2 rozhodl, že tím, že L. Borl nedostával ve vazební věznici v Litoměřicích veganskou, ale pouze vegetariánskou stravu, došlo k porušení jeho práva přiznaného $\mathrm{v}$ článku 15 Listiny základních práv a svobod - bylo porušeno jeho základní lidské právo na svobodu myšlení, svědomí.

${ }^{2}$ Článek 24 V̌̌eobecné deklarace lidských práv (OSN 2015, 50).

${ }^{3}$ Tvrzení Benioffa podle Osborne (2019). Viz také diskuse o lidských právech v kontextu transhumanismu (Saniotis 2009).

${ }^{4}$ Tvrdí Freedman a Isaacs (1993).
} 
filosofický. Aby je bylo možné zodpovědět, je třeba mít jasnou představu o tom, co to lidská práva jsou, na jakých základech stojí a čím jsou legitimizována. Pro určité účely stačí vymezení formální (či strukturální, jak jej nazývá Griffin, viz dále), jehož př́kladem je Dworkinův přistup, který se záměrně vyhýbá zasazení do nějakého metafyzického kontextu. ${ }^{5}$ Dworkin $(2001,12)$ ř́ká: „Individuální práva jsou politickými trumfy v rukou jednotlivcư“ - ačkoli naprostá většina zákonů, úkonů státu a vlády je v demokratických zemích řízena a legitimizována utilitárními ohledy na „kolektivní cíle“, což je v obecné rovině podle něj správně, pojem lidská práva označuje to, co má sílu „trumfnout" tyto kolektivní cíle ve prospěch zájmu jednotlivce. ${ }^{6} \mathrm{Za}$ obvyklých okolností je tedy možné jednotlivcům něco upírat či jim působit škodu, pokud to vyžadují „,kolektivní cíle“. Lidská práva představují nepřekročitelnou hranici, „trumf“"v rukou jednotlivců; jejich porušení není možné ani v zájmu kolektivních cílů, a pokud $\mathrm{k}$ němu dojde, je vždy bezprávím.

Pokud taková individuální práva, o kterých mluví Dworkin, označujeme jako „lidskác, je nezbytné jim podle Huntové $(2007,20)$ připsat určité základní charakteristiky - musíme je chápat jako práva přirozená, rovná a univerzální. Přrirozeností označuje skutečnost, že jsou inherentně vlastní každé lidské bytosti od jejího narození. Rovnost lidských práv znamená, že všichni lidé mají tatáž lidská práva a neexistují rozdíly mezi žádnými dvěma lidmi. Univerzálností míníme, že lidská práva se vztahují na všechny lidi, bez ohledu na místo jejich narození, kulturu, způsob života a národnost.

Tyto charakteristiky lidských práv v moderním pojetí můžeme kontrastovat s právy, jak je zakládá např́klad anglická Listina práv z roku 1689, která mluví o „starobylých a nezpochybnitelných právech a svobodách lidu tohoto královstvi"“.7 Zde je zřejmé, že tato práva nebyla chápána jako univerzální, ale pouze jako práva občanů konkrétního státu, která si historicky vydobyli na suverénovi, tudíž se vlastně jedná o určitá privilegia, která plynou $\mathrm{z}$ jejich občanství a jsou součástí tradičního společenského uspořádání dané konkrétní země. Názvy prvních souborů práv - Petition of Rights (1628), Bill of Rights (1689) - implikují vztah poddaných k nadřazené moci, suverénovi, který má práva garantovat. Naopak francouzská Déclaration

\footnotetext{
${ }^{5}$ Dworkin $(2001,12)$ ř́ká, že jeho charakteristika „,...) je samozřejmě formální v tom smyslu, že nenaznačuje, jaká práva lidé mají nebo garantují, (...). Nepředpokládá však, že práva mají nějakou zvláštní metafyzickou povahu (...)“.

${ }^{6}$ „Jednotlivci mají práva ve chvíli, kdy kolektivní cíl není z nějakého důvodu dostatečným ospravedlněním, aby se jim upiralo to, co jednotlivci chtějí mít nebo činit, nebo když není dostatečným ospravedlněním toho, aby se jim pưsobila nějaká škoda nebo újma“ (Dworkin 2001, 12).

${ }^{7}$ The English Bill of Rights (1689), cit. dle McClellan (2000, 80), zvýraznění autor stati. Překlad citací děl, u nichž odkazujeme na originální vydání v cizím jazyce, je prací autora článku.
} 
des droits de l'homme et du citoyen (1789) svým názvem indikuje stavění se do role suveréna. $^{8}$

Také zpochybňování lidských práv není jen předmětem současných filosofických prací (Nelson 1990), ale má relativně dlouhou historii. Např́klad Burke označoval lidská práva za produkt „,specialistů na intelektuální spekulace“, za projev „nejapné prohnanosti jejich politické metafyziky“ a zastával názor, že mohou být platná v teorii, ale neměla by ohrožovat praxi. ${ }^{9}$ Bentham $(1838,501)$ ve své slavné analýze francouzské Deklarace práv člověka a občana označil ideu přirozených lidských práv za „nesmysl na chůdách“. Vedle př́mého zpochybňování jsou dnes lidská práva vystavena i relativizaci, která omezuje jejich relevanci např́iklad na určitý kulturní okruh či geografickou oblast (Machan 1994, 482; Beyani 2012; Habermas 2008).

Cílem předkládaného textu nicméně není polemizovat s některou $\mathrm{z}$ těchto koncepcí zpochybňujících lidská práva a předložit argumenty zaměřené proti té či oné konkrétní teorii. Pokusíme se naopak odpovědět na otázku, zdali existuje širší shoda na tom, jakým způsobem by měl být koncept lidských práv založen a jak jej obecně legitimizovat. ${ }^{10}$

\section{Lidská práva jako evidentní}

V americké Deklaraci nezávislosti začíná pasáž týkající se lidských práv následujícími slovy: „Považujeme tyto pravdy za o sobě evidentní (...).“11 Za evidentní považovala lidská práva (nebo se alespoň $v$ tomto smyslu vyjadřovala) i celá řada osvícenských myslitelů - např. d'Holbach či Mirabeau. ${ }^{12}$ Tento postoj se také někdy zahrnuje pod etický intuicionismus (Twiss 2004, 60; Ignatieff 2001, 3 - 4). S takto formulovaným explicitním nárokem na evidentní pravdivost se však pojí určité problémy. Huntová $(2007,16,18)$ klade otázku, proč - pokud se jedná o evidentní pravdy - prošla americká Deklarace nezávislosti osmdesáti šesti revizemi před svou finální podobou? Proč v př́ípadě francouzské Deklarace práv člověka a občana debatovali o její podobě členové francouzského Ústavodárného národního shromáždění od 20. srpna 1789 šest

\footnotetext{
${ }^{8}$ Slovo déclaration ve staré francouzštině označovalo seznam pozemků, které feudální pán dával lénem svému vazalovi (Hunt 2007, 114).

${ }^{9}$ „Údajná práva těchto teoretiků jsou samé extrémy a úměrně své metafyzické pravdivosti jsou morálně a politicky falešná“ (Burke 1997, 68, 72).

${ }^{10}$ Habermas (2008) se také zabývá legitimizací v kontextu lidských práv, ale jde mu o jinou otázku: o otázku legitimizace demokratického ústavního politického rrádu prostřednictvím lidských práv. Jiný pohled na legitimizaci v rámci demokracie nabízí napřs. Špecián (2017).

${ }^{11}$ Declaration of independence, 1776, cit. dle Hunt (2007, 216). Anglický výraz self-evident překládáme jako evidentní.

${ }^{12}$ Viz Hunt $(2007,25)$. Vedle jmenovaných ovšem na rozvoji lidských práv participovala i celá řada dalších osvícenských myslitelů, např. Sieyes, Condorcet, Volney, Roederer a zejména Brissot (Israel 2011).
} 
dní a po nesčetném počtu připomínek a dodatků se obtížně shodli na výsledných sedmnácti článcích z navrhovaných dvaceti čtyř? Pokud se jedná o evidentní pravdy, jak je možné, že byly rozpoznány až v osmnáctém století v kontextu západní civilizace, a i dnes odmítají určití lidé či společenství je přijmout?

V současné době se k pojetí lidských práv jako evidentních nepřipojuje mnoho autorů. ${ }^{13}$ Jistým způsobem toto pojetí rozvíjejí dvě koncepce: Gewirthova, odvozující lidská práva logicky, vycházející z racionální evidence prováděné z perspektivy první osoby, ${ }^{14}$ a teorie Huntové, podle níž lze lidská práva evidentně nahlédnout v lidských emocích.

Gewirthovo pojetí umožňuje chápat lidská práva poměrně široce - pokrývají jak oblast polickou a občanskou, tak sociální a ekonomickou. ${ }^{15}$ Východiskem je mu člověk, jako iniciátor jednání ve světě, přičemž tato možnost jednat předpokládá určitý stav světa. Člověk, i zcela egoistický, musí chtít takový stav světa, aby mohl jednat, tj. aby byly splněny nutné podmínky pro možnost jeho jednání. Gewirth říká: „(...) každý jednající, nechce-li upadnout v kontradikci, musí předpokládat, že má práva na svobodu a prosperitu [well-being] jako na nutné podmínky svého jednání."“16 Další požadavek předchozí předpoklad univerzalizuje i na ostatní lidské bytosti a říká, že každá osoba „(...) má práva na svobodu a prosperitu vůči všem ostatním osobám a všechny ostatní osoby mají tato práva vůči ní (...)“. ${ }^{17}$ Lidská práva se tudíž primárně týkají vztahů lidí k sobě navzájem a až odvozeně vztahů vlády k lidem. Následně Gewirth postupuje pomocí řady logických odvozujících kroků a získává konkrétní systém lidských práv; postup pak nazývá ,argument z dostatečnosti schopnosti jednat“.18 Základní koncept zastřešující jeho teorii lidských práv označuje jako „princip generické konzistence“ a zní: „Jednej ve shodě jak s generickými právy svých protějšků, tak se svými."19 Jak však upozorňuje Kohen, pokud někdo nepovažuje nekonzistenci za zásadní problém svého jednání nebo druhé nepovažuje za (plnohodnotné) lidské bytosti, pak pro něj nebude Gerwithovo vyvození lidských práv relevantní. ${ }^{20}$

\footnotetext{
${ }^{13}$ Gewirth $(1984,5)$ řadí mezi intuicionisty i např. Nozicka (2005), kterého ovšem Machan (1980, 109) klasifikuje jako naturalistu.

${ }^{14}$ Gewirth $(1982,20)$ sám označuje svůj př́stup jako dialekticky nutnou metodu (dialectically necessary method). Je v tomto ohledu značně ovlivněn Hegelem, srv. Boylan $(1999,84)$, Chotaš (2003).

${ }^{15}$ Gewirth, A., Human Rights: Essays on Justification and Applications. Chicago: University of Chicago Press, 1983, s. x.

${ }^{16}$ Tamtéž, s. 5.

${ }^{17}$ Tamtéž, s. 18.

${ }^{18} \mathrm{~V}$ originále: Argument from the Sufficiency of Agency (ASA).

${ }^{19} \mathrm{~V}$ originále: „Principle of Generic Consistency (PGC)“. Gewirth, A.: The Epistemology of Human Rights, c. d., s. 17.

${ }^{20}$ Kohen, A. (2005): The Possibility of Secular Human Rights: Alan Gewirth and the Principle of Generic Consistency. Human Rights Review, 7 (1), s. 51. DOI: https://doi.org/10.1007/s12142-005-1002-3.
} 
Další koncepcí rozvíjející myšlenku lidských práv jako evidentních je teorie Huntové. Ta navrhuje na evidenci založenou legitimizaci lidských práv vycházející z emocí, říká: „Tvrzení evidentní pravdivosti závisí v konečném důsledku na emocionálním působení (...)“(Hunt 2007, 26). Výroky o lidských právech jsou přesvědčivé pouze tehdy, pokud emocionálně působí na každého člověka. Naše jistota ohledně toho, kdy jde o lidská práva, vychází z pocitu zhrození se v situacích, kdy jsou porušena. Huntová pritom na podporu své pozice cituje švýcarského přirozenoprávního filosofa Burlamaquie, který tvrdí: „Pocitové důkazy jsou nad všemi námitkami a vytvářejí nejhlouběji usazená přesvědčeni" (Burlamaqui 1747, 29; cit. dle Hunt 2007, 27). Jedině na základě vztahu k emocionálnímu prožívání je možné založit evidentní platnost všech tradičních zdrojů lidských práv: „Filosofické ideje, právní tradice a revoluční politika musí mít tento druh vnitřního emocionálního referenčního bodu, aby lidská práva byla skutečně ,evidentní ““ (ibid.). Toto emoční prožívání samozřejmě nemohlo být omezeno pouze na určitou skupinu - napřr. filosofů nebo intelektuálů, naopak muselo být široce sdíleno celou populací.

Za základ možnosti rozvoje tohoto emocionálního prožívání považuje Huntová $(2007,29)$ empatii a autonomii, které přitom nechápe abstraktně: „Autonomie a empatie jsou kulturní praktiky, nikoli jen ideje, a jsou tudíž doslova vtěleny, tj. mají fyzickou stejně jako emocionální dimenzi.“ Důraz se zde skutečně dává na historický proces, ve kterém se lidé nejen psychologicky, ale fyzicky osamostatňovali, tedy získávali autonomii. Příkladem je pak samostatné spaní, používání př́iborů, zvyšování studu ohledně tělesných funkcí a obecně narůstající pocit separace a osobního vlastnictví těla. Tato tělesná separace pak zároveň vedla k možnosti empatie s druhými.

Ve vazbě na kulturní praktiky, které jsou základem emočního prožívání, jež funduje lidská práva, také tkví určité limity tohoto př́stupu. Poměrně dobře sice umožňuje vysvětlit historii a nástup koncepce lidských práv v západním světě, ale obtížněji může sloužit jako prostředek univerzální legitimizace jejich platnosti pro jiné kultury s jinými tradičními praktikami a jinak rozvinutým emočním prožíváním.

\section{Lidská práva jako založená v lidské přirozenosti}

Zakotvení lidských práv v lidské přirozenosti má historickou souvislost s koncepcemi přrirozeného zákona a práva, jejichž původ je v moderní filosofii spojován se jmény Hobbese, Grotia a Locka, historicky je však možné související úvahy nalézt i ve středověké filosofii, u stoiků a dalších antických filosofü (např. Cicero 2009, 29).

Podobná kritika viz Chitty, A.: Protagonist and subject in Gewirth's argument for human rights. King's Law Journal, 19 (1), 2008, s. 1 - 26. 
Explicitně se k přirozenoprávnímu založení lidských práv a k této historické tradici hlásí především libertariánská filosofie, kde se téma lidských práv objevuje v textech Randové (1967), Macka (1973; 1976; 1974) a ve formě pokusu o syntézu těchto pozic u Machana (1982). ${ }^{21}$ Východiskem je zde objektivistická, egoistická etická teorie, ve které je to život jednotlivce, jenž je ,ontologickým základem hodnot“, z čehož plyne, že ,[b]ez fenoménů růstu zaměřeného na možnost úspěšného dosažení cíle, jak je to evidentní v príípadě čehokoli živého, fakt, že něco je dobré nebo špatné, se zdá nedávat žádného smyslu“ (Machan 1982, 62). Bez živých bytostí zde nemůže být nic, co by bylo dobré nebo špatné pro někoho. Člověk je přitom svou přirozeností bytostí rozumnou a zároveň společenskou. Práva Machan dělí na speciální (např. dětí vůči rodičům), morální (např. dodržování smluv) a přirozená. Přirozená práva člověka jsou ,principy života komunity, které jsou na základě přirozenosti lidských bytostí náležitě dodržovány všemi členy komunity“ (Machan 1982, 63). Konkrétně se jedná o práva na život, svobodu a vlastnictví. Právo na život je př́mo implikováno přirozeností člověka jako živé bytosti. Právo na svobodu je dáno tím, že zachování života člověka vyžaduje určitá aktivní jednání, která musí být povolena. Podobně právo na vlastnictví je dáno tím, že zachování života a prosperita vyžaduje produkci nejrůznějších hodnotných statků, což je možné jen tehdy, pokud tyto činnosti nebudou narušovány ostatními lidskými bytostmi, a to zajišt'uje právě institut vlastnictví. ${ }^{22}$ Výsledkem je pak libertariánský politický systém, který podle Machana jako jediný plně odpovídá tomuto konceptu lidských práv. Problémem tohoto př́stupu k lidským právům podle jeho kritiků je, že vede k systému, který je mimořádně rigidní, a při své důsledné aplikaci by vedl k fatálním důsledkům pro rozvoj lidstva (Sobel 2012).

Mezi přirozenoprávní teoretiky můžeme jistým způsobem řadit i výše citovaného Dworkina. Ačkoli se ve svém vymezení vyhýbá použití nějaké konkrétní metafyzické teorie pro definování lidských práv a jeho definice je ryze formální, sám se posléze hlásí k založení lidských práv a práva obecně v přirozenoprávní koncepci: „Normativní teorie bude zasazena v obecnější politické a morální filosofii, jež sama zase závisí na filosofických teoriích lidské přirozenosti či objektivnosti morálky“ (Dworkin 2001, 9). ${ }^{23}$ Toto plánované budoucí zasazení teorie lidských práv do širšího filosofického kontextu, který by je jakožto přirozená legitimizoval, však nebylo nikdy Dworkinem realizováno. ${ }^{24}$

${ }^{21}$ Historické metafyzické kořeny těchto úvah u Misese sleduje např. Špecián (2012).

${ }^{22}$ Srv. Pošvanc (2009).

${ }^{23}$ Překlad upraven, zvýraznění autor stati. V originále: „The normative theory will be embedded in a more general political and moral philosophy (..)“; český překlad chybně uvádí v př́itomném čase „Normativní teorie má kořeny v obecnější politické a morální filosofii (...)“.

${ }^{24}$ Upozorňuje na to např. Machan $(1980,111)$. 


\section{Utilitaristické založení lidských práv}

Dalším možným zdůvodněním významu lidských práv je, že se jedná o prostředek $\mathrm{k}$ dosažení pro všechny lidi důležitých cílů, které přispívají $\mathrm{k}$ všeobecnému dobru a štěstí všech lidí. Všeobecná deklarace lidských prav OSN $(2015,1)$ říká, že uznání „(...) nezcizitelných práv členů lidské rodiny je základem svobody, spravedlnosti a míru ve světě“. Dále je tento argument znovu prezentován v opačné podobě, tedy že opomenutí lidských práv má za důsledek nejen nedosažení pro všechny lidi důležitých cílů, ale dokonce historicky vedlo k zavrhovaným důsledkům, umenšujícím všeobecné dobro; zmiňovaný dokument také varuje, že „zneuznání lidských práv a pohrdání jimi vedlo k barbarským činům“ (ibid.). Lidská práva tedy nejsou v tomto př́padě chápána jako hodnota sama o sobě, ale jako principy, jejichž dodržování vede k pro člověka hodnotným důsledkům a naopak jejich nedodržování vede $\mathrm{k}$ pro člověka nepř́ijemným či nepřijatelným důsledkům. V úvodu tohoto textu jsme již ovšem viděli, že zakladatel utilitarismu Bentham zásadním způsobem ideu lidských práv odmítal. Nicméně již jeho následovník Mill ve svém díle určitý prostor teorii lidských práv otevřel, když v závěru svého Utilitarismu (2011, 117, 128, 147 - 149) rozpracoval obecnou teorii spravedlnosti a práv.

Z hlediska současné utilitaristické teorie, jak ji prezentuje např. Gibbard (1984, 92), jde o otázku návrhu správných společenských institucí, př́padně obecněji společenských praktik - ty jsou následně hodnoceny na základě svého výkonu (performance), přičemž hodnotící kritéria sama žádné odkazy na práva neobsahují. Liberální utilitaristé tvrdí, že implementace lidských práv do návrhu společenských institucí vede $\mathrm{k}$ nejlepšímu řešení $\mathrm{z}$ hlediska utilitárních kritérií. Jedná se o jistou formu utilitarismu pravidel. Gibbard $(1984,93)$ ř́ká: „Hlavní důvod, proč si ceníme tato práva, je ochrana, kterou nabízejí: perspektiva, že jejich uznání povede k rozvoji lidského vzkvétání a štěstí.“

Obvyklou námitkou je, že utilitarista respektující striktně lidská práva musí bud' věřit tomu, že porušení lidských práv nikdy není nejlepší cestou zajištění všeobecného dobra, nebo musí být připraven obětovat všeobecné dobro, pokud by jednání na něj cílící vedlo $\mathrm{k}$ porušení lidských práv. V prvním případě je otázkou, jak je možné takovou jistotu získat a zdali skutečně takové přesvědčení může platit. $V$ druhém případě pak utilitarista přestává být utilitaristou.

Utilitaristé na tuto námitku odpovídají, že porušení lidských práv ve většině př́ipadů maří cestu ke všeobecnému dobru. Existují výjimky, ale podle Gibbarda (1984, 99) „lidské názory, které př́pady počítat za tyto výjimky, jsou notoricky nespolehlivé“, ,i pečliví výzkumníci by došli k malé shodě spolu navzájem, které př́ípady jsou výjimkami“, a ti ostatní by se nebyli schopni shodnout, kterým expertům důvěřovat. Závěrem tak je, že nelze určit, jak by měl fungovat institut rozhodující o tom, které 
př́pady jsou výjimky umožňující porušení lidských práv, proto je nejvhodnější zavést institut automatického odsouzení jakýchkoliv aktů porušujících lidská práva. Ve výsledku je Gibbard přesvědčen, že i utilitarista může konzistentně hájit koncepci lidských práv.

\section{Založení lidských práv na pojmu důstojnosti}

Když se znovu vrátíme $\mathrm{k}$ Všeobecné deklaraci lidských práv, můžeme si všimnout, že mluví o „(...) uznání přirozené důstojnosti a rovných a nezcizitelných práv členů lidské rodiny $(. .$.$) “ (OSN 2015, 1). Tuto formulaci můžeme chápat jako odkaz na to, že$ jedním ze způsobů, jak založit lidská práva, je vyjít od pojmu důstojnosti člověka, který je ve filosofické tradici nejčastěji spojován s dílem Immanuela Kanta.

Kant $(1907,230)$ sám používal pouze pojem „přirozená práva“ a ta odvozoval $\mathrm{z}$ apriorních principů, konkrétně $\mathrm{z}$ všeobecného principu práva. ${ }^{25}$ Tato přirozená práva „,náleží každému člověku na základě jeho lidství“ (ibid., 237). V pasážích svého díla věnovaných přirozeným právům (a právu obecně) přitom pojem důstojnosti nezmiňuje, nebot' ten u něj spadá do oddílů věnovaných morální filosofii, kde se jím pak zabývá detailněji (ibid., 434). Obě části jeho díla - právní a morální - jsou propojeny pojmem osoby jako „subjektu morálního praktického rozumu“ (ibid.), tudíž nadaného svobodou. Současné koncepce důstojnosti jako základu lidských práv přitom vycházejí právě z oddílů Kantova textu věnovaných morální oblasti (ibid., 434 - 436). ${ }^{26}$

V současné filosofii někteří autoři pokládají Kantovo založení pojmu důstojnosti za pro evropskou kulturu zásadní. Berger tvrdí, že koncept důstojnosti (dignity) nahradil starší koncept cti (honor). Čest je „(...) spojena s hierarchickým uspořádáním společnosti““ ${ }^{27}$ Západní pojem cti byl pak spojen se středověkými rytiřskými kódy cti a feudálními sociálními strukturami a od nich byl převzat i moderními hierarchickými sociálními strukturami, které najdeme u aristokracie nebo armády, př́padně v tradičních profesích, jako je medicína nebo právo. Čest definuje povinnosti vůči sobě rovným v sociální struktuře, ale i vůči těm, kteří stojí níže a výše. Selhání pak zasahuje nejen jedince, ale i jeho rodinu, př́padně celou komunitu. Berger přitom odkazuje na Campbellova $(1974,271)$ etnografická zkoumání vztahů cti v rurálních oblastech Řecka: „Čest považovaná za držbu těchto kvalit muži a ženami je pokusem vztáhnout existenci k určitým archetypálním vzorům chování." Podle Bergera $(1983,174)$ je taková na cti založená kultura „esenciálně premoderni“ a lze předpokládat její „rozklad po srážce s modernitou“. Historicky k tomuto rozkladu nedošlo prrímo, ale

\footnotetext{
25 Širší kontext Kantova pojetí práva viz Chotaš (2002).

${ }^{26} \mathrm{~V}$ tomto kontextu je nutné poukázat na to, že Kant (1907, 329 - 330) připouští, že člověk může spácháním zločinu důstojnost ztratit.

${ }^{27}$ Berger $(1983,174)$. Původní vydání: Berger (1970).
} 
prostřednictvím „buržoazizace“ cti, která tento pojem rozložila a vytvořila prostor pro pojem důstojnosti (Elias 1939).

Pojem důstojnosti je od pojmu cti zásadně odlišný, $\operatorname{Berger}(1983,176)$ říká: „Důstojnost, v protikladu ke cti, se vždy vztahuje k esenciálnímu (intrinsic) lidství, zbavenému všech sociálně předepsaných rolí nebo norem." Důstojnost je tedy charakteristikou ,(...) já (self), zbaveného, nebo pokud preferujete osvobozeného od mystifikací cti (...)“ (ibid., 175), a „(...) je to přesně toto osamocené já, které moderní vědomí vnímalo jako nositele lidské důstojnosti a nezcizitelných lidských práv (...) (ibid., 176). Toto reálné já člověka je nad a za všemi biologickými a společenskými diferenciacemi.

Bergerův výklad je ovšem možné využít $\mathrm{k}$ poukazu na určitou problematičnost pojmu důstojnosti v současném diskurzu, nebot' upozorňuje, že důstojnost stejně jako čest vyžadují „,vědomé úsilí pro své udržování“ a mohou být „získány, směněny, uchovány nebo ohroženy“ a ,jejich ztráta je vždy možná, s dalekosáhlými důsledky pro já“ (ibid.). To je v souladu s používáním pojmu důstojnost v běžném každodenním diskurzu. Empirický výzkum např́ílad ukazuje, že mladí lidé někdy říkají, že si „,důstojnost ještě nevydobyli“, naopak lidé středního věku vyjadřují obavu, že „důstojnost ztratí" s odchodem do důchodu (EC 2004, 12; srv. Popovičová 2009, 226). Proti tomu ovšem je nutno namítnout, že má-li být lidská důstojnost základem nezcizitelných lidských práv, pak také tato důstojnost musí být cosi, co lidská bytost nemůže ztratit.

Tento rozpor je možné vyřešit poukazem na to, že každodenní význam slova důstojnost $\mathrm{v}$ sobě nese ještě významové nánosy pojmu cti - pokud se někdo domnívá, že důstojnost je nezbytné si dobýt, pak ji zřejmě chápe jako něco vztaženého ke své pozici v hierarchické sociální struktuře, což je významová charakteristika nikoli důstojnosti, ale právě cti. Důstojnost člověka musí být naopak na jeho pozici v sociální hierarchii nezávislá, má-li být základem na pozici v sociální hierarchii nezávislých lidských práv. Zarážející je nicméně skutečnost, že toto částečné pojmové zmatení najdeme i u Bergera.

Jasně oddělené pojmy cti a důstojnosti najdeme následně u Taylora. Vymezuje významné společenské změny, které byly předpokladem nástupu demokratických státních zřizení, říká: „Je to předně zhroucení společenských hierarchií, které dříve tvořily základ cti. Používám zde pojmu čest (honor) ve smyslu, jaký měl v ancien régime, kde byl úzce spjat s nerovností. Má-li čest v tomto smyslu náležet některým lidem, pak nemůže př́slušet každému“ (Taylor 2004, 46). To je také do jisté míry nepřesné, nebot' čest $\mathrm{v}$ tradičním slova smyslu mohla náležet všem, ale každému jiná čest. Čest rytî̌re byla jiná než čest poctivého řemeslníka. Fakticky ovšem ve většině tradičních společenství byli i lidé nebo skupiny, kterým žádná čest nebyla přiznána (Pease 1926). Důstojnost proti tomu je výslovně přiznána všem: „V určitém pro- 
tikladu k tomuto pojmu cti stojí moderní pojem důstojnosti (dignity), který užíváme $\mathrm{v}$ univerzalistickém a egalitárním smyslu (...). Jeho základem je předpoklad, že se na této důstojnosti podílí každý člověk“" (Taylor 2004, 46). ${ }^{28}$ Závěrem můžeme říci, že má-li být pojem důstojnosti základem koncepce lidských práv, musí být chápán právě a jen $\mathrm{v}$ univerzalistickém a egalitárním smyslu a musí být zbaven pojmových zmatení. ${ }^{29}$

Nejvýznamnějším ze současných autorů, který navazuje na koncepci důstojnosti jako východiska lidských práv, je pravděpodobně Griffin $(2008,33)$, který ovšem volí za základ své teorie pojem bytí osobou: „Na čem bychom měli říci, že jsou založena lidská práva? Dobrá, primárně na bytí osobou. $Z$ pojmu bytí osobou je možné vyge-

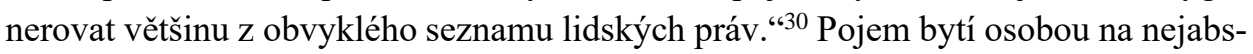
traktnější úrovni přitom zahrnuje svobodu, autonomii a minimální zabezpečení, jakožto ochranu statusu člověka jako normativního jednajícího (ibid., 61). Vedle bytí osobou jsou základem lidských práv tzv. praktikality; Griffin odmítá chápat osobu čistě kantovsky jako noumenon, ale je třeba vzít v úvahu určité charakteristiky lidské přirozenosti a přirozenosti lidských společností (ibid., 37 - 38). Přirozenost však chápe expanzivněji než Hume, nebot' pod ni zahrnuje např́íklad i lidské zájmy (ibid., 36). Tím se jeho pojetí snaží určitým způsobem integrovat i přirozenoprávní koncepce. Griffin uvažuje i o rovnosti jako o základu lidských práv, ale po detailní diskusi ji odmítá, nebot' trpí ambivalencí a nejasností svého pojmového vymezení (ibid., 44).

Griffin $(2008,61)$ říká, že mezi jeho a Kantovým pojetím lidských (resp. pririrozených) práv je velký překryv, nicméně např́klad jeho pojetí svobody je odlišné a taktéž klade větší důraz na přirozené lidské charakteristiky. Výsledkem tak je poměrně omezený seznam lidských práv, přičemž Griffin explicitně odmítá „nafukování“ tohoto seznamu přidáváním dalších a dalších položek (ibid., 220).

\section{Závěr}

Výše uvedené rozdělení způsobů legitimizace lidských práv nepovažujeme za rigidní, řada představených koncepcí svou povahou tyto kategorie přesahuje nebo by bylo možné je zařadit do více skupin. Toto třídění také není jediné možné. ${ }^{31}$ Např́ílad

\footnotetext{
${ }^{28}$ Jistou otázkou je, co je míněno výrazem ,„podílí“ (shares); zdali je to výraz Taylorova platonismu. Killius (2017) se ptá explicitně: „Je Taylor skrytým platonikem?“'V naší stati ovšem není tato otázka podstatná.

${ }^{29}$ Pokus o rozvinutí pojmu důstojnosti jako základu lidských práv najdeme i u Habermase (2013), viz také Pavlovičová (2015).

${ }^{30}$ Výraz ,personhood“ překládáme do češtiny jako „bytí osobou“.

${ }^{31}$ Ve slovenském kontextu Šmihula (2001) rozlišuje př́stup náboženský, korporativní, přirozenoprávní, pozitivistický, historicko-právní a sociopolitický. Mezi náboženské myslitele můžeme řadit i českou fillosofku Komárkovou (1986), která se ve svém díle snažila vyrovnat s faktem, že někteří dřivější katoličtí myslitelé ideu lidských práv zcela odmítli. Jistou návaznost na úvahy Komárkové
} 
Machan $(1980,103)$ rozlišuje dva základní druhy teorií: kognitivistické a nekognitivistické. Mezi nekognitivistické teorie spadají takové, jejichž metaetická pozice zahrnuje odmítnutí možnosti vysvětlení, dokázání nebo jiného způsobu lidskému rozumu př́stupného založení morálních pojmů, a tedy i lidských práv. Všechny ostatní teorie, tedy ty, které racionální vysvětlení připouštějí, pak řadí mezi kognitivistické.

Mezi nekognitivistické teorie by pak patřilo například chápání lidských práv jako evidentních, které jsme popsali v úvodu tohoto textu. Vedle toho mezi ně Machan zahrnuje i další koncepce, které jsme v našem textu nezmiňovali, např́iklad MacDonaldovou $(1967,49)$, která říká: „Tvrdit, že ,Svoboda je lepší než otroctví nebo že ,Všichni lidé mají stejnou hodnotu', neznamená sdělovat fakt, ale zvolit si stranu. Říkám tím: ,To je, za čím si stojím‘ “" Další vysvětlení tohoto rozhodnutí není už možné. Podobně např́klad Melden $(1977,180)$ vychází z Austinovy (2000) koncepce řečových aktů a chápe výroky o lidských právech jako určitou komplikovanou performanci. Mezi nekognitivistické koncepce by dále patřily i některé historizující teorie, např́klad Luhmannova (1965), jež klade základ moderního pojetí lidských práv do procesu sebediferenciace sociálních systémů, který vedl k posunu od vztahů založených na podřizenosti $\mathrm{k}$ modelům založeným na souřadnosti.

Jinou klasifikaci teorií lidských práv navrhuje výše zmiňovaný Griffin (2008, 20, 27), který rozlišuje strukturální, substantivní a legálně-funkcionální přístupy. Strukturální př́istupy charakterizují lidská práva na základě jejich role ve struktuře všech práv a zahrnují například v úvodu zmíněné pojetí Dworkinovo, koncepci Feinbergovu (1974) a částečně i Nozickovu (2005). Substantivní teorie oproti tomu vycházejí z nějakého obecněji etického nebo metafyzického základu, na němž se pokouší legitimizovat lidská práva - hlavní z nich jsme se pokusili zmapovat v tomto textu. Mezi legálně-funkcionální př́stupy řadí Griffin např́íklad Rawlse (1999) nebo na něj navazujícího Beitze $(2009 ; 2004 ; 2003)$. Rawls se pokusil odvodit lidská práva jako principy multikulturní společnosti, která je však uspořádaná (well-ordered), ovšem výsledný seznam práv je mimořádně redukovaný - nezahrnuje např́íklad svobodu projevu, svobodu sdružování, práva na demokratickou participaci na vládě a žádná ekonomická práva nad rámec pouhé subsistence (Rawls $1999,65,70,74,79)$, přičemž hlavní rolí lidských práv je u něj legitimizace spravedlivé války (ibid., 20, $79-80$ ). ${ }^{32}$

Na v úvodu položenou otázku, je možné odpovědět, že v současnosti neexistuje širší shoda na tom, jakým způsobem by měl být koncept lidských práv založen a jak jej obecně legitimizovat. Existují určité průsečíky mezi jednotlivými koncepcemi, ani tak však nelze zatím nalézt ucelený jednotící př́stup, který by byl obecně přijímaný.

lze vysledovat v pojetí lidských práv u Hejdánka (1998) či Trojana (2002). Jejich diskusi o lidských právech mapuje článek Havlíčka (2014).

${ }^{32}$ Viz komplexní kritika Rawlsova pojetí lidských práv v Griffin (2008, 22 - 27). 
$\mathrm{Z}$ určitého pohledu se může zdát, že to není problém; jak řekl Maritain, člen komise UNESCO, která připravovala Všeobecnou deklaraci lidských práv, když se ho ptali, jak je možné, že se tak kulturně různorodá skupina dokáže shodnout na seznamu lidských práv: „shodneme se na právech, ovšem za podmínky, že se nikdo neptá proč“ (cit. dle Griffin 2008, 25). Po praktické stránce je ovšem nutné mít vodítka pro řešení situací zahrnujících konflikty mezi různými lidskými právy, jejich aplikaci nebo pro návrhy rozšíření stávajících seznamů o další položky. $Z$ obecnějšího hlediska je tak třeba se pokusit vypracovat spolehlivý filosofický teoretický základ konceptu lidských práv, jež zatím, jak se zdá, není plně k dispozici, jinak bude jen obtížně možné argumentačně obhajovat koncept lidských práv proti zpochybňujícím, relativizujícím a odmítajícím hlasům.

\section{Literatura}

ARISTOTELÉS (2013): Etika Nikomachova. Praha: Rezek.

AUSTIN, J. L. (2000): Jak udělat něco slovy. Praha: Filosofia.

BEITZ, Ch. R. (2003): What Human Rights Mean. Daedalus, 132 (1), 36 - 46.

BEITZ, Ch. R. (2004): Human Rights and The Law of Peoples. In: Chatterjee, D. K. (ed.): The Ethics of Assistance: Morality and the Distant Needy. Cambridge: Cambridge University Press. DOI: https://doi.org/10.1017/CBO9780511817663.011

BEITZ, Ch. R. (2009): The Idea of Human Rights. Oxford University Press.

BENTHAM, J. (1838): Anarchical Fallacies. In: The Works of Jeremy Bentham. Vol. 2. Edinburgh: William Tait.

BERGER, P. (1970): On the Obsolence of the Concept of Honor. European Journal of Sociology, $11(2), 339-347$.

BERGER, P. (1983): On the Obsolence of the Concept of Honor. In: Hauerwas, S., MacIntyre, A. (eds.): Revisions: Changing Perspectives in Moral Philosophy. Notre Dame (Indiana): Notre Dame University Press.

BEYANI, Ch. (2012): Reconstituting the Universal: Human Rights as a Regional Idea. In: Gearty, C. (ed.): The Cambridge Companion to Human Rights Law, 173 - 190. Cambridge: Cambridge University Press. DOI: http://dx.doi.org/10.1017/CCO9781139060875.014

BOYLAN, M. (ed.) (1999): Gewirth: Critical Essays on Action, Rationality, and Community. Lanham (Maryland): Rowman \& Littlefield.

BURKE, E. (1997): Úvahy o revoluci ve Francii. Brno: CDK.

BURLAMAQUI, J.-J. (1747): Principes Du Droit Naturel. Geneva: Barrillot et fils.

CAMPBELL, J. K. (1974): Honour, Family and Patronage. Oxford: Oxford University Press.

CHOTAŠ, J. (2002): Locke a Kant o právu na soukromé vlastnictví. Filosofický časopis, 50 (1), 47 - 70.

CHOTAŠ, J. (2003): Hegelova teorie mravního státu. Filosofický časopis, 51 (2), 275 - 291.

CICERO (2009): O Věcech veřejných. Praha: Oikoymenh.

DWORKIN, R. M. (2001): Když se práva berou vážně. Praha: Oikoymenh.

EC (2004): Respektování lidské di̊stojnosti. Praha: Cesta domů.

ELIAS, N. (1939): Über Den Prozess Der Zivilisation: Soziogenetische Und Psychogenetische Untersuchungen. Haus Zum Palken.

FEINBERG, J. (1974): Rights of Animals and Unborn Generations. In Blackstone, W. T. (ed.): Philosophy and Environmental Crisis. Athens, Georgia: University of Georgia Press.

FREEDMAN, L. P., ISAACS, S. L. (1993): Human Rights and Reproductive Choice. Studies in Family Planning, 24 (1), 18 - 30. DOI: https://doi.org/10.2307/2939211 
GEWIRTH, A. (1978): Reason and Morality. Chivago: University of Chicago Press.

GEWIRTH, A. (1982): Human Rights: Essays on Justification and Applications. Chicago: University of Chicago Press.

GEWIRTH, A. (1984): The Epistemology of Human Rights. Social Philosophy and Policy, 1 (2), 1. DOI: http://dx.doi.org/10.1017/S0265052500003836

GIBBARD, A. (1984): Utilitarianism and Human Rights. Social Philosophy and Policy, 1 (2), 92. DOI: http://dx.doi.org/10.1017/S0265052500003897

GRIFFIN, J. (2008): On Human Rights. Oxford: Oxford University Press.

HABERMAS, J. (2008): K legitimizaci prostřednictvím lidských práv. In: Hrubec, M. (ed.): Interkulturní dialog o lidských právech: západní, islámské a konfuciánské perpektivy. Praha: Filosofia.

HABERMAS, J. (2013): Koncept lidské důstojnosti a realistická utopie lidských práv. In: J. Habermas: $K$ Ustaveni Evropy. Praha: Filosofia.

HAVLÍČEK, A. (2014): Jsou lidská práva přirozená? Reflexe, 47, 131 - 137.

HEJDÁNEK, L. (1998): Lidská práva a filosofie. Křestanská Revue, 65, $148-153$.

HUNT, L. (2007): Inventing Human Rights: A History. 1st ed. New York: W.W. Norton \& Co.

IGNATIEFF, M. (2001): Human Rights as Politics and Idolatry. Princeton: Princeton University.

ISRAEL, J. (2011): Democratic Enlightenment: Philosophy, Revolution, and Human Rights 1750 1790. Oxford: Oxford University Press.

KANT, I. (1907): Die Metaphysik Der Sitten. In: Kant, I.: Kants Gesammelte Schriften, Vol. VI. Berlin: Herausgegeben von der Königlich Preußischen Akademie der Wissenschaften.

KILLIUS, M. (2017): The Ambivalence of Charles Taylor's Philosophy: What Makes Our Everyday Reality Real? Dialogue, 56 (4): 669 - 679.

KOHEN, A. (2005): The Possibility of Secular Human Rights: Alan Gewirth and the Principle of Generic Consistency. Human Rights Review, 7 (1), 49 - 75. DOI: https://doi.org/10.1007 /s12142-005-1002-3

KOMÁRKOVÁ, B. (1986): Pưvod a význam lidských práv. Affoltern am Albis (Switzerland): Cramerius.

LUHMANN, N. (1965): Grundrechte Als Institution. Berlin: Duncker \& Humblot.

MACDONALD, M. (1967): Natural Rights. In: Laslett, P. (ed.): Philosophy, Politics and Society, Oxford: Blackwell.

MACHAN, T. R. (1980): Some Recent Work in Human Rights Theory. American Philosophical Quarterly, 17 (2), $103-115$.

MACHAN, T. R. (1982): A Reconsideration of Natural Rights Theory. American Philosophical Quarterly, 19 (1): 61-72.

MACHAN, T. R. (1994): Human Rights Reaffirmed. Philosophy, 69 (270), 479 - 490.

MACK, E. (1973): Egoism and Rights. Pacific Philosophical Quarterly, 54 (1), 5.

MACK, E. (1974): Individualism, Rights, and the Open Society. In: Machan, T. R. (ed.): The Libertarian Alternative. Chicago: Nelson-Hall.

MACK, E. (1976): Hart on Natural and Contractual Rights. Philosophical Studies, 29 (4), 283 - 285.

MCCLELLAN, J. (2000): Liberty, Order, and Justice: An Introduction to the Constitutional Principles of American Government. Indianapolis: Liberty Fund.

MELDEN, A. I. (1977): Rights and Persons. University of California Press.

MILL, J. S. (2011): Utilitarismus. Praha: Vyšehrad.

NELSON, J. O. (1990): Against Human Rights. Philosophy, 65 (253), 341 - 348.

NOZICK, R. (2005): Anarchie, stát a utopie. Praha: Academia.

OSBORNE, Ch. (2019): Artificial Intelligence Will Become the next New Human Right. Dostupné online na: https://www.zdnet.com/article/artificial-intelligence-will-become-the-next-newhuman-right/ (Navštívené: 24. 1. 2019).

OSN (2015): V̌̌eobecná deklarace lidských práv. Dostupné online na: http://www.osn.cz/wpcontent/uploads/2015/12/UDHR_2015_11x11_CZ2.pdf (Navštívené: 1. 3. 2020).

PAVLOVIČOVÁ, Z. (2015): Ambivalentnost' ludských práv a neurčitost' ich pojmu z pohl'adu filozofie. Filozofia, 70 (9), 759 - 769. 
PEASE, A. S. (1926): Things without Honor. Classical Philology, 21 (1), 27 - 42.

POPOVIČOVÁ, D. (2009): Lidská důstojnost jako filosoficko-právní pojem. Časopis pro právní védu a praxi, č. 3.

POŠVANC, M. (2009): Vlastníctvo ako inherentná súčast' spoločenských vzt'ahov. E-Logos -Electronic Journal for Philosophy, 16 (19).

RAND, A. (1967): Man's Rights. In: Rand, A. (ed.): Capitalism: The Unknown Ideal. New York: New American Library.

RAWLS, J. (1999): The Law of Peoples. Harvard University Press.

SANIOTIS, A. (2009): Human Enhancement Technologies, Transhumanism and Religion. E-Logos - Electronic Journal for Philosophy, 16 (4).

ŠMIHULA, D. (2001): O podstatě l'udských práv. Filozofia, 56 (6).

SOBEL, D. (2012): Backing Away from Libertarian Self-Ownership. Ethics, 123 (1), 32 - 60. DOI: http://dx.doi.org/10.1086/667863

ŠPECIÁN, P. (2012): Svět a věda u Ludwiga von Misese. Esej o misesovské metafyzice. Filozofia, 67 (4), $335-346$

ŠPECIÁN, P. (2017): Economic Analysis of a Referendum. Politická Ekonomie, 65 (4), 460 - 475. DOI: https://doi.org/10.18267/j.polek.1155.

TAYLOR, Ch. (2004): Zkoumáni politiky uznání. Multikulturalismus. Praha: Epocha.

TROJAN, J. S. (2002): Idea lidských práv v české duchovní tradici. Vyd. 1. Edice Oikúmené. Praha: Oikoymenh.

TWISS, S. B. (2004): History, Human Rights, and Globalization. The Journal of Religious Ethics, 32 (1), 39 - 70. DOI: http://dx.doi.org/10.1111/j.0384-9694.2004.00154.x

Miroslav Vacura

Vysoká škola ekonomická v Praze

Katedra filosofie

Nám. W. Churchilla 1938/4

13067 Praha 3 - Žižkov

Česká republika

e-mail: vacuram@vse.cz

ORCID ID: https://orcid.org/0000-0002-7989-4427 